\section{'Sharpe', a Clonal Plum Rootstock for Peach}

Thomas G. Beckman ${ }^{1,4}$

U.S. Department of Agriculture, Agricultural Research Service, Southeastern Fruit and Tree Nut Research Laboratory, 21 Dunbar Road, Byron, GA 31088

Jose X. Chaparro² and Wayne B. Sherman ${ }^{3}$

University of Florida, Department of Horticultural Sciences, 1143 Fifield Hall, Hull Road, Gainesville, FL 32611

Additional index words. Prunus persica, P. angustifolia, Armillaria, peach tree short life, PTSL, root-knot nematode

'Sharpe' rootstock has been jointly released for grower trial by the U.S. Department of Agriculture, Agricultural Research Service (Byron, GA) and Florida Agricultural Experiment Station. 'Sharpe' is suggested for trial as a rootstock for peach (Prunus persica L. Batsch) varieties on Armillaria root rot (ARR) [Armillaria tabescens (Scop.:Fr.) Dennis et al.] infested sites where peach seedlingtype rootstocks often fail to provide satisfactory tree longevity. Peach varieties budded onto 'Sharpe' rootstock display resistance to peach tree short life (PTSL) comparable to that of trees budded onto Guardian peach seedling rootstock. 'Sharpe' also appears to provide a marked reduction in tree vigor compared with peach seedling-type rootstocks and may prove useful as a semidwarf rootstock in which a less vigorous tree is preferred.

\section{Origin}

'Sharpe' is a putative plum hybrid rootstock of unknown origin discovered in Florida by the late Prof. Ralph Sharpe and tested under the designation of FLA1-1 (Sharpe, 1974). 'Sharpe' is so named to honor Dr. Sharpe's long and distinguished service to the U.S. peach industry as both a cultivar and rootstock breeder. 'Sharpe' appears to be a hybrid of Chickasaw plum [Prunus angustifolia (Marsh.)] with an unknown plum species (Beckman, personal observation).

\section{Description}

Unbudded trees of 'Sharpe' display moderate vigor and a semiupright form. Flowers are small and white with yellow anthers. At the Byron location, bloom typically coincides with peach cultivars requiring $\approx 500 \mathrm{~h}$ of chilling below $7{ }^{\circ} \mathrm{C}(45 \mathrm{~F})$ to break the rest period. Trees require crosspollination to set fruit. Fruit are small (typically 3 to $4 \mathrm{~cm}$ in diameter), soft, and sweet with yellow skin and flesh. 'Sharpe' is readily propagated through softwood or hardwood cuttings.

Received for publication 30 Nov. 2007. Accepted for publication 29 Aug. 2008.

${ }^{1}$ Research Horticulturist.

${ }^{2}$ Assistant Professor.

${ }^{3}$ Professor Emeritus.

${ }^{4}$ To whom reprint requests should be addressed; e-mail Tom.Beckman@ars.usda.gov
In field trials in central Georgia on a site with a known history of PTSL, trees budded on 'Sharpe' provided resistance to PTSL comparable to those budded on Guardian ${ }^{\mathrm{TM}}$ (BY5209) peach seedling rootstock (Table 1), the current industry standard (Beckman and Lang, 2003; Okie et al., 1994). In field trials in central Georgia on an Armillaria (A. tabescens) infested site, trees budded on 'Sharpe' displayed better resistance to ARR than did those budded on Guardian (Table 2). Susceptibility to ARR is a significant weakness of Guardian rootstock (Beckman et al., 1997, 1998).

In a field trial in central Georgia on a site infested with the Southern root-knot nematode (Meloidogyne incognita), 'Sharpe' displayed no visible galling comparable to Nemaguard seedlings, which are regarded as resistant to this nematode (Sharpe, 1974). In the same trial, Lovell seedlings, regarded as susceptible to $M$. incognita (Sharpe, 1974), were severely galled. In a field trial in northern Florida on a site infested with M. floridensis, 'Sharpe' displayed no visible galling comparable to Flordaguard seedlings, which are regarded as resistant to this nematode (Sherman et al., 1991). In the same trial, Nemaguard seedlings, regarded as susceptible to $M$. floridensis (Sherman et al., 1991), were severely galled.

In a horticultural field trial in central Georgia, trees budded on 'Sharpe' displayed significantly lower vigor than those budded on Guardian (Table 3). After six growing seasons, trunk cross-sectional area of trees budded on 'Sharpe' was $\approx 60 \%$ of those budded on Guardian rootstock. Hence, 'Sharpe' may prove useful as a semidwarf (or tree sizereducing) rootstock for peach.

Trees budded on 'Sharpe' generally displayed lower annual yields on a per-tree basis than those budded on Guardian (Table 4). However, this is in part the result of the lower vigor of 'Sharpe' rootstock. When expressed as yield efficiency (yield per unit trunk crosssectional area), trees budded on 'Sharpe' were still generally lower but not always significantly different from those budded on Guardian (Table 5). This suggests that if trees on 'Sharpe' were planted at a higher density to compensate for their lower vigor, then per-hectare yields at maturity might approach those budded on Guardian. Trees budded on 'Sharpe' displayed lower average fruit weight than those budded on Guardian (Table 6), although differences were not always significant. Over the course of this study, fruit weight was, on average, $10 \%$ smaller on 'Sharpe' than on Guardian, which could be a problem if varieties with borderline size for their intended use or ripening season were used. Trees budded on 'Sharpe' generally produced fewer root suckers than did trees budded on Guardian, although differences were not statistically significant (Table 7).

'Sharpe' has been tested for compatibility with a range of peach and nectarine scions, including 'Delta', 'Fireprince', 'Flordaguard', 'Gulfcrest', 'Harvester', 'Majestic', 'Redhaven', 'Rubyprince', and 'Summergrand', all of which displayed satisfactory compatibility (observation periods range from 3 to 10 years and are still in progress). Graft unions with peach scions are typically smooth or may display a slight scion overgrowth as the trees mature. 'Sharpe' also displayed satisfactory compatibility with 'Ozark Premier' $(P$. salicina) and 'Stanley' $(P$. domestica) plum scions in short-term trials (2 to 3 years). Long-term compatibility with plum scions, however, has not yet been established. Compatibility was poor when grafted with 'Non Pareil' or 'Mission' almond scions and also with the apricot selection CVN5A.

\section{Availability}

'Sharpe' has been released in the public domain. Neither the USDA-ARS nor the University of Florida have trees of 'Sharpe' for distribution. Genetic material of this release has been deposited in the IR-2 Fruit Tree Collection where it is available for research purposes, including development and commercialization of new varieties or rootstocks. Virus-indexed budwood is available from National Virus-Tested Fruit Tree Program, WSU-IAREC, 24106 N. Bunn Road, Prosser, WA 99350-9687.

Table 1. Rootstock influence on the cumulative tree mortality (\%) resulting from peach tree short life (PTSL) of 'Redhaven' peach trees planted on a severe PTSL site ${ }^{z}$ (Byron, 1996 to 2002).

\begin{tabular}{lllllll}
\hline & \multicolumn{5}{c}{ Year } \\
\cline { 2 - 6 } Rootstock & $1997 \quad 1998 \quad 1999$ & 2000 & 2001 & 2002 \\
\hline
\end{tabular}
\begin{tabular}{lllllll}
\hline Sharpe $^{\mathrm{y}}$ & 2 & $4 \mathrm{~b}^{\mathrm{x}}$ & $4 \mathrm{~b}$ & $4 \mathrm{~b}$ & $14 \mathrm{~b}$ & $14 \mathrm{~b}$
\end{tabular} $\begin{array}{lllllll}\text { Guardian }^{w} & 0 & 0 \mathrm{~b} & 0 \mathrm{~b} & 2 \mathrm{~b} & 16 \mathrm{~b} & 18 \mathrm{~b}\end{array}$ $\begin{array}{lllllll}\mathrm{BY} 90 \mathrm{P} 3211^{\mathrm{v}} & 2 & 28 \mathrm{a} & 42 \mathrm{a} & 46 \mathrm{a} & 52 \text { a } & 58 \mathrm{a}\end{array}$

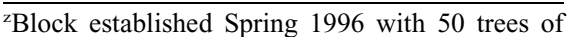
each scion/rootstock combination in a randomized, complete block design with 10 replications of five tree plots each.

yPropagated through hardwood cuttings.

${ }^{\mathrm{x}}$ Mean separation within columns by WallerDuncan test, $\mathrm{k}$ ratio $=100$. Cumulative percent mortality data were transformed as arcsine (square root) before analysis (Gomez and Gomez, 1984); untransformed means presented. Data analyzed by general linear models (GLM) program of the Statistical Analysis System for personal computers (SAS Institute, Inc., 2003).

${ }^{\mathrm{w}}$ Commercial bulked seedlot.

veach seedling line developed in Byron cultivar breeding program. A homozygous red-leafed, 'evergreen' selection out of an open-pollinated population of BY87P312 = Rutgers Redleaf $\times$ PI442380 (Mexican Evergreen). 
Table 2. Rootstock influence on the cumulative tree mortality (\%) as a result of Armillaria root rot (ARR) of 'Redhaven' peach trees planted on a severe ARR site ${ }^{\mathrm{z}}$ (Byron, 2000 to 2006).

\begin{tabular}{lllcccr}
\hline & \multicolumn{5}{c}{ Year } \\
\cline { 2 - 7 } Rootstock & 2001 & 2002 & 2003 & 2004 & 2005 & 2006 \\
\hline Sharpe $^{\mathrm{y}}$ & 0 & 0 & 6 & 10 & 16 & 20 \\
Guardian $^{\mathrm{x}}$ & 0 & 4 & 18 & 32 & 47 & 49 \\
Significance $(P)^{\mathrm{w}}$ & 1.000 & 0.168 & 0.253 & 0.114 & 0.098 & 0.099
\end{tabular}

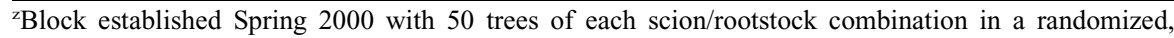
complete block design with 10 replications of five tree plots each.

y Propagated through hardwood cuttings.

${ }^{\mathrm{x}}$ Guardian selection SL2891 (component of bulk commercial lot).

${ }^{\text {w Significance }}(P)$ of difference between means in each column, $\mathrm{F}$ test. Percent mortality data were transformed as arcsine (square root) before analysis (Gomez and Gomez, 1984); untransformed means presented. Data analyzed by general linear models (GLM) program of the Statistical Analysis System for personal computers (SAS Institute, Inc., 2003).

Table 3. Rootstock influence on trunk cross-sectional area $\left(\mathrm{cm}^{2}\right)$ of 'Redhaven' peach trees planted on a site in central Georgia ${ }^{\mathrm{y}}$ (Byron, 2000 to 2005).

\begin{tabular}{lccccr}
\hline & \multicolumn{5}{c}{ Year } \\
\cline { 2 - 6 } Rootstock & 2001 & 2002 & 2003 & 2004 & 2005 \\
\hline Sharpe $^{\mathrm{x}}$ & 15.8 & 33.3 & 51.6 & 64.8 & 83.0 \\
Guardian $^{\mathrm{w}}$ & 26.6 & 45.2 & 87.9 & 113.1 & 136.2 \\
Significance $(P)^{\mathrm{v}}$ & 0.003 & 0.046 & 0.009 & 0.006 & 0.014 \\
\hline
\end{tabular}

${ }^{\mathrm{z}}$ Estimated from trunk diameter measured $30 \mathrm{~cm}$ above soil line.

${ }^{y}$ Block established Spring 2000 in a randomized, complete block design with eight single-tree replications of each rootstock treatment. Trees were trained to a two-arm open-center design and otherwise managed according to commercial recommendations. Supplemental irrigation was applied through a drip system during periods of prolonged drought.

xPropagated through hardwood cuttings.

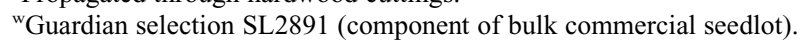

vSignificance $(P)$ of difference between means in each column, F test. Data analyzed by general linear models (GLM) program of the Statistical Analysis System for personal computers (SAS Institute, Inc., 2003).

Table 4. Rootstock influence on yield ( $\mathrm{kg} /$ tree) of 'Redhaven' peach trees planted on a site in central Georgia $^{z}$ (Byron, 2000 to 2005).

\begin{tabular}{lllccc}
\hline & \multicolumn{5}{c}{ Year } \\
\cline { 2 - 6 } Rootstock & 2002 & 2003 & 2004 & 2005 & Cumulative \\
\hline Sharpe $^{\mathrm{y}}$ & 1.9 & 11.6 & 8.2 & 4.4 & 26.2 \\
Guardian $^{\mathrm{x}}$ & 5.6 & 26.9 & 13.0 & 13.4 & 55.4 \\
Significance $(P)^{\mathrm{w}}$ & 0.011 & 0.001 & 0.001 & 0.003 & $<0.001$
\end{tabular}

${ }^{\mathrm{z} B}$ lock established Spring 2000 in a randomized, complete block design with eight single-tree replications of each rootstock treatment. Trees were trained to a 2-arm open-center design and otherwise managed according to commercial recommendations. Supplemental irrigation was applied through a drip system during periods of prolonged drought.

yPropagated through hardwood cuttings.

${ }^{\mathrm{x}}$ Guardian selection SL2891 (component of bulk commercial seedlot).

${ }^{\text {wSignificance }}(P)$ of difference between means in each column, F test. Data analyzed by general linear models (GLM) program of the Statistical Analysis System for personal computers (SAS Institute, Inc., 2003).

Table 5. Rootstock influence on yield efficiency $\left(\mathrm{kg} \cdot \mathrm{cm}^{-2}\right)$ of 'Redhaven' peach trees planted on a site in central Georgiaz (Byron, 2000 to 2005).

\begin{tabular}{lllllc}
\hline & \multicolumn{5}{c}{ Year } \\
\cline { 2 - 6 } Rootstock & 2002 & 2003 & 2004 & 2005 & Cumulative \\
\hline Sharpe $^{\mathrm{y}}$ & 0.06 & 0.23 & 0.13 & 0.05 & 0.32 \\
Guardian $^{\mathrm{x}}$ & 0.12 & 0.33 & 0.13 & 0.10 & 0.43 \\
Significance $(P)^{\mathrm{w}}$ & 0.032 & 0.105 & 0.929 & 0.024 & 0.111 \\
\hline
\end{tabular}

${ }^{\mathrm{z} B}$ block established Spring 2000 in a randomized, complete block design with eight single-tree replications of each rootstock treatment. Trees were trained to a two-arm open-center design and otherwise managed according to commercial recommendations. Supplemental irrigation was applied through a drip system during periods of prolonged drought.

yPropagated through hardwood cuttings.

${ }^{\mathrm{x}}$ Guardian selection SL2891 (component of bulk commercial seedlot).

wSignificance $(P)$ of difference between means in each column, F test. Data analyzed by general linear models (GLM) program of the Statistical Analysis System for personal computers (SAS Institute, Inc., 2003).

\section{Literature Cited}

Beckman, T.G. and G.A. Lang. 2003. Rootstock breeding for stone fruits. Acta Hort. 622:531551.

Beckman, T.G., W.R. Okie, A.P. Nyczepir, P.L. Pusey, and C.C. Reilly. 1998. Relative susceptibility of peach and plum germplasm
Table 6. Rootstock influence on fruit weight $(\mathrm{g} /$ fruit) of 'Redhaven' peach trees planted on a site in central Georgiaz (Byron, 2000 to 2005).

\begin{tabular}{lcccc}
\hline & \multicolumn{4}{c}{ Year } \\
\cline { 2 - 5 } Rootstock $^{2002}$ & 2003 & 2004 & 2005 \\
\hline Sharpe $^{\mathrm{y}}$ & 120 & 123 & 149 & 144 \\
Guardian $^{\mathrm{x}}$ & 124 & 124 & 176 & 166
\end{tabular}

Significance

$\begin{array}{lllll}(P)^{\mathrm{w}} & 0.509 & 0.885 & 0.010 & 0.143\end{array}$

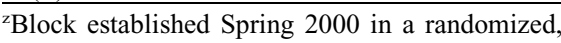
complete block design with eight single-tree replications of each rootstock treatment. Trees were trained to a two-arm open-center design and otherwise managed according to commercial recommendations. Trees were hand thinned by a commercial crew 30 to $45 \mathrm{~d}$ after full bloom, fruit evenly spaced 10 to $15 \mathrm{~cm}$ apart throughout the canopy. Supplemental irrigation was applied through a drip system during periods of prolonged drought.

${ }^{\text {y }}$ Propagated through hardwood cuttings.

${ }^{\mathrm{x}}$ Guardian selection SL2891 (component of bulk commercial seedlot).

"Significance $(P)$ of difference between means in each column, $F$ test. Data analyzed by general linear models (GLM) program of the Statistical Analysis System for personal computers (SAS Institute, Inc., 2003).

Table 7. Rootstock influence on root suckering (number/tree) of 'Redhaven' peach trees planted on a site in central Georgia ${ }^{z}$ (Byron, 2000 to 2005).

\begin{tabular}{llllll}
\hline & \multicolumn{5}{c}{ Year } \\
\cline { 2 - 6 } Rootstock & 2002 & 2003 & 2004 & 2005 & Cumulative \\
\hline Sharpe $^{\mathrm{y}}$ & 0.0 & 1.3 & 1.4 & 1.6 & 4.3 \\
Guardian $^{\mathrm{x}}$ & 1.9 & 3.5 & 0.5 & 1.0 & 6.9 \\
$\begin{array}{l}\text { Significance } \\
(P)^{\mathrm{w}}\end{array}$ & 0.059 & 0.142 & 0.443 & 0.696 & 0.526 \\
\hline
\end{tabular}

${ }^{\mathrm{z} B}$ lock established Spring 2000 in a randomized, complete block design with eight single-tree replications of each rootstock treatment. Trees were trained to a two-arm open-center design and otherwise managed according to commercial recommendations. Supplemental irrigation was applied through a drip system during periods of prolonged drought.

${ }^{y}$ Propagated through hardwood cuttings.

${ }^{\mathrm{x}}$ Guardian selection SL2891 (component of bulk commercial seedlot).

${ }^{\text {w Significance }}(P)$ of difference between means in each column, F test. Data analyzed by general linear models (GLM) program of the Statistical Analysis System for personal computers (SAS Institute, Inc., 2003).

Gomez, K.A. and A.A. Gomez. 1984. Statistical procedures for agricultural research. Wiley, New York, NY.

Okie, W.R., T.G. Beckman, A.P. Nyczepir, G.L. Reighard, W.C. Newall Jr., and E.I. Zehr. 1994. BY520-9, a peach rootstock for the southeastern United States that increases scion longevity. HortScience 29:705-706.

SAS Institute, Inc. 2003. SAS for Windows, Version 9.1. SAS Institute, Inc., Cary, NC.

to Armillaria root rot. HortScience 33:10621065.

Beckman, T.G., W.R. Okie, A.P. Nyczepir, G.L. Reighard, E.I. Zehr, and W.C. Newall. 1997. History, current status and future potential of Guardian $^{\mathrm{TM}}$ (BY520-9) peach rootstock. Acta Hort. 451:251-258.
Sharpe, R.H. 1974. Breeding peach rootstocks for the southern United States. HortScience 9: 362-363.

Sherman, W.B., P.M. Lyrene, and R.H. Sharpe. 1991. Flordaguard peach rootstock. HortScience 26:427-428. 